\title{
Isolation and Insecticidal/Anthelmintic Activity of Xanthonol, a Novel Bis-xanthone, from a Non-sporulating Fungal species
}

\author{
John G. Ondeyka, Anne W. Dombrowski, Jon P. Polishook, Tom Felcetto, \\ Wesley L. Shoop, Ziqiang Guan, Sheo B. Singh
}

Received: February 24, 2006 / Accepted: May 10, 2006

(C) Japan Antibiotics Research Association

\begin{abstract}
Xanthonol, a novel dimeric xanthone, was isolated from a fermentation broth of a non-sporulating fungal species using Sephadex LH20 followed by HPLC and the structure elucidated by spectral analysis. Xanthonol exhibited insecticidal and anthelmintic activities against larvae of Lucilia sericata, Aedes aegypti, and Haemonchus contortus with $\mathrm{LD}_{90}$ of 33,8 , and $50 \mu \mathrm{g} / \mathrm{ml}$, respectively.
\end{abstract}

Keywords non-sporulating fungus, xanthonol, insecticide, anthelmintic

\section{Introduction}

We have recently reported the discovery of a fungal metabolite mellamide [1] as an insecticidal agent which represented another compound in a long list of insecticidal and anthelmintic agents from our laboratories that include avermectins [2], paraherquamides [3], and nodulisporic acid [4], isolated from both prokaryotic and eukaryotic sources. Ecto and endo parasites, such as fleas, ticks, and intestinal worms, pose significant health hazards to humans and their domestic animals. Insecticides and anthelmintics, even with the latest approved treatments, are limited by their therapeutic index, environmental safety, development of resistance, and/or lack of systemic effects. Discovery of safe and efficacious systemic antiparasitic drugs with new modes of action are critically and continuously needed to

J. G. Ondeyka (Corresponding author), A. W. Dombrowski, J. P. Polishook, T. Felcetto, W. L. Shoop, Z. Guan, S. B. Singh: Merck Research Laboratories, Merck \& Co., Inc. PO Box 2000, R80Y-355, Rahway, New Jersey 07065 USA,

E-mail: john_ondeyka@merck.com

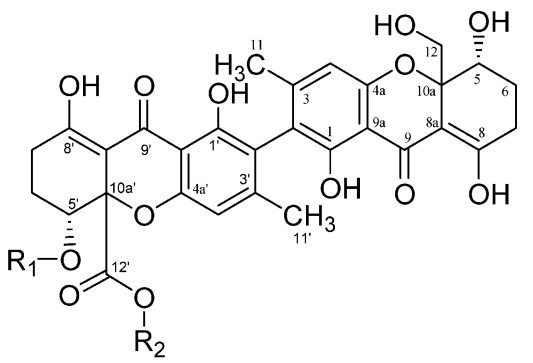
1. $R_{1}=$

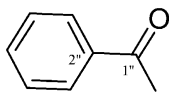
$\mathrm{R}_{2}=\mathrm{CH}_{3}$
2. $\mathrm{R}_{1}=$
$\mathrm{H}$
$\mathrm{R}_{2}=\mathrm{H}$

Fig. 1 Structure of xanthonol (1) and hydrolysis product (2).

effectively treat human and animal infections.

Our continued interest in novel antiparasitic agents led us to screen extracts of fungal fermentations in in vitro antiparasitic assays using surrogate organisms such as blowfly larvae, Lucilia sericata [5], mosquito larvae, Aedes aegypti [6], and a parasitic nematode of sheep, Haemonchus contortus [7]. This screening strategy led to the isolation and identification of xanthonol (1), a new dimeric xanthone from an extract of a non-sporulating fungal species (Figure 1). This report describes the details of the producing strain, isolation, structure determination and biological activities of xanthonol (1).

\section{Materials and Methods}

\section{General Procedures}

The NMR experiments were conducted on a Varian Unity 
$500 \mathrm{MHz}$ instrument using a dual $3 \mathrm{~mm}$ probe. All 1D and 2D experiments such as ${ }^{1} \mathrm{H},{ }^{13} \mathrm{C}$, COSY, DEPT, NOESY, $\mathrm{HMQC}$ and $\mathrm{HMBC}$ were recorded in $\mathrm{CD}_{3} \mathrm{CN}$ or $\mathrm{CD}_{3} \mathrm{OD}$. Residual solvent peaks were used as internal reference $\left(\mathrm{CD}_{3} \mathrm{CN}: \delta_{\mathrm{H}} 1.94\right.$ and $\delta_{\mathrm{C}} 118.7$ and $\mathrm{CD}_{3} \mathrm{OD}: \delta_{\mathrm{H}} 3.30$ and $\delta_{\mathrm{C}}$ 49.0). ESI-LC-MS was used for determination of molecular weight with a Thermo-Finnigan LCQ. High resolution mass measurement was performed on a ThermoFinnigan NewStar 3T FT/MS instrument. UV visible spectra were recorded on a Beckman DU 70 spectrophotometer. Optical rotation was determined on a Perkin-Elmer 241 polarimeter. Analytical HPLC was performed on HP 1100 liquid chromatograph with a diode array detector (DAD) and Chemstation software (HewlettPackard, Palo Alto, USA). Preparative HPLC was performed on a Gilson system using Unipoint software.

\section{Antiparasitic Assays}

Details of the antiparasitic assays have been described elsewhere for Aedes aegypti [5]; Lucilia sericata [6]; and Haemonchus contortus [7].

\section{Growth Conditions for the Fungal Strain}

The non-sporulating fungus, MF6460, was isolated from a leaf litter of Manilkara bidentata collected in El Verde, Puerto Rico. The culture is maintained in the Merck culture collection at Merck Research Laboratories, Rahway, New Jersey and is available upon request.

The culture was inoculated into seed flasks by aseptically transferring a $1 \mathrm{ml}$ aliquot of the frozen vegetative mycelium into a $250 \mathrm{ml}$ Erlenmeyer flask, containing $50 \mathrm{ml}$ seed medium of the following composition: corn steep powder $2.5 \mathrm{~g} /$ liter, tomato paste $40 \mathrm{~g} /$ liter, glucose $10 \mathrm{~g} /$ liter, oat flour $10 \mathrm{~g} /$ liter and trace elements $10 \mathrm{ml}$ consisting of $\mathrm{FeSO}_{4} \cdot 7 \mathrm{H}_{2} \mathrm{O} 1.0 \mathrm{~g} /$ liter, $\mathrm{MnSO}_{4} \cdot \mathrm{H}_{2} \mathrm{O} 1.0 \mathrm{~g} /$ liter, $\mathrm{CuCl}_{2}$. $2 \mathrm{H}_{2} \mathrm{O} 0.025 \mathrm{~g} /$ liter, $\mathrm{CaCl}_{2} 0.1 \mathrm{~g} /$ liter, $\mathrm{H}_{3} \mathrm{BO}_{3} 0.056 \mathrm{~g} /$ liter, $\left(\mathrm{NH}_{4}\right)_{6} \mathrm{Mo}_{7} \mathrm{O}_{24} \cdot 4 \mathrm{H}_{2} \mathrm{O} 0.019 \mathrm{~g} /$ liter, $\mathrm{ZnSO}_{4} \cdot 7 \mathrm{H}_{2} \mathrm{O} 0.2 \mathrm{~g} /$ liter and adjusted to $\mathrm{pH} 6.8$. The seed medium was prepared in distilled water, and was dispensed into $250 \mathrm{ml}$ Erlenmeyer flasks and capped with cotton plugs before being autoclaved at $121^{\circ} \mathrm{C}$ for 20 minutes. The seed culture was incubated at $25^{\circ} \mathrm{C}, 220 \mathrm{rpm}$ and $85 \%$ relative humidity for 2 days, and then transferred to the production medium.

Fermentations were performed either in solid state on vermiculite or in liquid media. The production phase, for solid state fermentations, was grown in 4-liter roller bottles, containing approximately $1250 \mathrm{ml}$ (measured by volume) of large-particle vermiculite (sterilized separately from the liquid), with $440 \mathrm{ml}$ of a liquid nutrient solution poured over it at the time of inoculation. The nutrient solution was formulated as follows: glycerol $40 \mathrm{~g} /$ liter, glucose
$300 \mathrm{~g} /$ liter, yeast extract $8.0 \mathrm{~g} /$ liter, $\mathrm{Na}_{2} \mathrm{HPO}_{4} 2.0 \mathrm{~g} /$ liter, monosodium glutamate $6.0 \mathrm{~g}, \mathrm{NaNO}_{3} 2.0 \mathrm{~g} /$ liter, $\mathrm{MgSO}_{4}$. $7 \mathrm{H}_{2} \mathrm{O} 2.0 \mathrm{~g} /$ liter, $\mathrm{CaCO}_{3} 16.0 \mathrm{~g} /$ liter, and $\mathrm{K}$ elements $1 \mathrm{ml}$. (The $\mathrm{K}$ element solution was prepared as follows: $\mathrm{FeCl}_{3} \cdot 6 \mathrm{H}_{2} \mathrm{O} 5.8 \mathrm{~g} /$ liter, $\mathrm{NaMoO}_{4} \cdot 2 \mathrm{H}_{2} \mathrm{O} 0.5 \mathrm{~g} /$ liter, $\mathrm{MnSO}_{4}$. $\mathrm{H}_{2} \mathrm{O} 0.1 \mathrm{~g} /$ liter, $\mathrm{CuSO}_{4} \cdot 5 \mathrm{H}_{2} \mathrm{O} 0.015 \mathrm{~g} /$ liter, $\mathrm{CoCl}_{2} \cdot 6 \mathrm{H}_{2} \mathrm{O}$ $0.02 \mathrm{~g} /$ liter, $\mathrm{ZnCl}_{2} \quad 0.02 \mathrm{~g} /$ liter, $\mathrm{SnCl}_{2} \cdot 2 \mathrm{H}_{2} \mathrm{O}, \mathrm{H}_{3} \mathrm{BO}_{3}$ $0.01 \mathrm{~g} /$ liter, $\mathrm{KCl} 0.02 \mathrm{~g} /$ liter in conc. $\mathrm{HCl}$ ). The $\mathrm{pH}$ of the medium was adjusted to 7.0 before adding $\mathrm{CaCO}_{3}$. The production medium was dispensed in $110 \mathrm{ml}$ aliquots in $500 \mathrm{ml}$ bottles and autoclaved 15 minutes at $121^{\circ} \mathrm{C}$. The solid and liquid portions of the production medium were combined and inoculated with $20 \sim 24 \mathrm{ml}$ of the seed culture. The 4-liter roller bottle was shaken to coat the vermiculite with the seed growth and nutrient solution. Incubation was on a Wheaton roller apparatus rotating at approximately $4 \mathrm{rpm}$, at $22^{\circ} \mathrm{C}$ and $70 \%$ relative humidity, for 19 days. Production of active component was low.

The production phase for liquid fermentation was grown in $250 \mathrm{ml}$ shake flasks, containing approximately $50 \mathrm{ml}$ of liquid medium with inoculums. The nutrient solution was formulated as follows: glycerol $75 \mathrm{~g} /$ liter, glucose $50 \mathrm{~g} /$ liter, ardamine $\mathrm{pH} 5.0 \mathrm{~g} /$ liter, soybean meal $5.0 \mathrm{~g} /$ liter, tomato paste $5.0 \mathrm{~g}$ /liter, sodium citrate $2.0 \mathrm{~g} /$ liter, $\left(\mathrm{NH}_{4}\right)_{2} \mathrm{SO}_{4}$ $2.0 \mathrm{~g} /$ liter. The production medium was dispensed in $250 \mathrm{ml}$ shake flasks and autoclaved for 15 minutes at $121^{\circ} \mathrm{C}$. An aliquot of $2.0 \mathrm{ml}$ of seed fermentation was added to the $50 \mathrm{ml}$ of production medium and allowed to incubate at $22^{\circ} \mathrm{C}$ in a Forma room on a shaker at $220 \mathrm{rpm}$ and $70 \%$ relative humidity for 21 days.

\section{Isolation of Xanthonol (1)}

A 3-liter fermentation of the fungus grown in shake flasks was extracted with 3-liters of methyl ethyl ketone and the organic layer separated and concentrated under reduced pressure using a rotary evaporator to an aqueous solution. The yellow aqueous solution was sequentially extracted with $75 \mathrm{ml}$ of $\mathrm{CH}_{2} \mathrm{Cl}_{2}$, followed by $200 \mathrm{ml}$ of EtOAc and the remaining aqueous layer was freeze dried. The $\mathrm{CH}_{2} \mathrm{Cl}_{2}$ and EtOAc extracts were combined and concentrated to give an oil which was triturated with hexane and filtered to yield $350 \mathrm{mg}$ of a solid. The freeze dried solid (4.3 g) was triturated with hexane $(200 \mathrm{ml})$ and filtered to yield $3 \mathrm{~g}$ of a solid. Both solids were combined and dissolved in $120 \mathrm{ml}$ of $\mathrm{MeOH}$ and charged to a 4-liter Sephadex LH20 column in $\mathrm{MeOH}$ and eluted at a flow rate of $20 \mathrm{ml} /$ minute resulting in $1.52 \mathrm{~g}$ of highly enriched xanthonol in $1.15 \sim 1.25$ column volumes. This material was further purified by reversed phase preparative HPLC using Waters Symmetry $\mathrm{C}_{18}$ column $(21 \times 250 \mathrm{~mm})$ eluting with $50 \%$ aqueous $\mathrm{CH}_{3} \mathrm{CN}$ at a flow rate of $8 \mathrm{ml} /$ minute at ambient temperature 
Table $1{ }^{13} \mathrm{C}$ and ${ }^{1} \mathrm{H}$ NMR assignments of xanthonol (1) in $\mathrm{CD}_{3} \mathrm{CN}(500 \mathrm{MHz}, \delta$ in ppm)

\begin{tabular}{|c|c|c|c|c|}
\hline Carbon & $\delta_{\mathrm{C}}$ & Type & $\delta_{\mathrm{H}}($ mult, $J$ in $\mathrm{Hz}$ ) & $\mathrm{HMBC}$ \\
\hline 1 & 160.3 & Q & & \\
\hline $1^{\prime}$ & 160.5 & $\mathrm{O}$ & & \\
\hline 2 & 118.3 & Q & & \\
\hline $2^{\prime}$ & 116.8 & $\mathrm{Q}$ & & \\
\hline 3 & 151.3 & O & & \\
\hline $3^{\prime}$ & 150.3 & $\mathrm{Q}$ & & \\
\hline 4 & 109.7 & $\mathrm{CH}$ & 6.36 (s) & $2,4 a, 9 a, 11$ \\
\hline $4^{\prime}$ & 110.5 & $\mathrm{CH}$ & 6.45 (s) & $2^{\prime}, 4 a^{\prime}, 9 a^{\prime}, 11^{\prime}$ \\
\hline $4 a$ & 158.0 & $\mathrm{Q}$ & & \\
\hline $4 a^{\prime}$ & 158.8 & $\mathrm{Q}$ & & \\
\hline 5 & 66.6 & $\mathrm{CH}$ & $4.26(\mathrm{dd}, 2.0,4.5)$ & $7,10 a, 8 a$ \\
\hline $5^{\prime}$ & 68.9 & $\mathrm{CH}$ & $5.88(\mathrm{dd}, 2.0,4.5)$ & $1^{\prime \prime}, 8 a^{\prime}, 7^{\prime}, 10 a^{\prime}$ \\
\hline \multirow[t]{2}{*}{6} & 23.0 & $\mathrm{CH}_{2}$ & $2.00(\mathrm{~m})$ & \\
\hline & & & $2.00(\mathrm{~m})$ & \\
\hline \multirow[t]{2}{*}{$6^{\prime}$} & 24.0 & $\mathrm{CH}_{2}$ & $2.12(\mathrm{~m})$ & \\
\hline & & & $2.22(\mathrm{~m})$ & $5^{\prime}, 8^{\prime}, 10 a^{\prime}$ \\
\hline \multirow[t]{2}{*}{7} & 25.6 & $\mathrm{CH}_{2}$ & $2.30(\mathrm{dd}, 20,6.5)$ & $5,6,8,8 a$ \\
\hline & & & 2.65 (ddd, 19, 8.0, 6.5) & $6,8,8 a$ \\
\hline \multirow[t]{2}{*}{$7^{\prime}$} & 25.5 & $\mathrm{CH}_{2}$ & $2.52(\mathrm{dd}, 20,6.5)$ & $5^{\prime}, 8^{\prime}, 8 a^{\prime}$ \\
\hline & & & $2.83(\mathrm{ddd}, 19,8.0,6.5)$ & $6^{\prime}, 8^{\prime}, 8 a^{\prime}$ \\
\hline $8 a$ & 102.6 & Q & & \\
\hline $8 a^{\prime}$ & 101.7 & $\mathrm{Q}$ & & \\
\hline 8 & 180.3 & Q & & \\
\hline $8^{\prime}$ & 180.2 & Q & & \\
\hline $9 a$ & 105.4 & $\mathrm{Q}$ & & \\
\hline $9 a^{\prime}$ & 105.4 & O & & \\
\hline 9 & 188.2 & Q & & \\
\hline $9^{\prime}$ & 188.7 & $\mathrm{O}$ & & \\
\hline $10 a$ & 84.9 & O & & \\
\hline $10 a^{\prime}$ & 83.3 & Q & & \\
\hline 11 & 20.8 & $\mathrm{CH}_{3}$ & 1.97 (s) & $2,3,4$ \\
\hline $11^{\prime}$ & 20.8 & $\mathrm{CH}_{3}$ & $1.95(\mathrm{~s})$ & $2^{\prime}, 3^{\prime}, 4^{\prime}$ \\
\hline \multirow[t]{2}{*}{12} & 65.8 & $\mathrm{CH}_{2}$ & $3.50(\mathrm{dd}, 12.0,7.5)$ & $5,10 a$ \\
\hline & & & $3.78(\mathrm{dd}, 12.0,5.5)$ & $5,10 a$ \\
\hline $12^{\prime}$ & 171.3 & $\mathrm{O}$ & & \\
\hline $13^{\prime}$ & 54.3 & $\mathrm{CH}_{3}$ & 3.73 (s) & $12^{\prime}$ \\
\hline $1^{\prime \prime}$ & 166.1 & $\mathrm{O}$ & & \\
\hline $2^{\prime \prime}$ & 130.7 & $\mathrm{O}$ & & \\
\hline $3^{\prime \prime}$ & 130.6 & $\mathrm{CH}$ & $8.01(\mathrm{dd}, 8.0,1.5)$ & $1^{\prime \prime}, 5^{\prime \prime}, 7^{\prime \prime}$ \\
\hline $4^{\prime \prime}$ & 129.7 & $\mathrm{CH}$ & $7.47(t, 7.5)$ & $2^{\prime \prime}, 6^{\prime \prime}$ \\
\hline $5^{\prime \prime}$ & 134.5 & $\mathrm{CH}$ & $7.61(t, 8.0)$ & $3^{\prime \prime}, 7^{\prime \prime}$ \\
\hline $6^{\prime \prime}$ & 129.7 & $\mathrm{CH}$ & $7.47(t, 7.5)$ & $2^{\prime \prime}, 4^{\prime \prime}$ \\
\hline $7^{\prime \prime}$ & 130.6 & $\mathrm{CH}$ & $8.01(\mathrm{dd}, 8.0,1.5)$ & $1^{\prime \prime}, 3^{\prime \prime}, 5^{\prime \prime}$ \\
\hline $12-\mathrm{OH}$ & & & $3.12(\mathrm{dd}, 7.5,5.5)$ & 12 \\
\hline $5-\mathrm{OH}$ & & & $3.25(\mathrm{~m})$ & 6 \\
\hline $1-\mathrm{OH}$ & & & 11.59 (s) & $1,2,9 a$ \\
\hline $1^{\prime}-\mathrm{OH}$ & & & 11.48 (s) & $1^{\prime}, 2^{\prime}, 9 a^{\prime}$ \\
\hline $8-\mathrm{OH}$ & & & $14.01(\mathrm{~s})$ & $7,8,8 a$ \\
\hline $8^{\prime}-\mathrm{OH}$ & & & 14.03 (s) & $7^{\prime}, 8^{\prime}, 8 a^{\prime}$ \\
\hline
\end{tabular}

yielding $1.5 \mathrm{~g}$ (500 mg/liter) of xanthonol (1), as a yellow amorphous powder.

\section{Hydrolysis of Xanthonol (1)}

A $50 \mathrm{mg}$ aliquot of $\mathbf{1}$ was dissolved in tetrahydrofuran. A $3 \mathrm{ml}$ saturated solution of $\mathrm{LiOH}$ was added slowly at room temperature while stirring. After 2 hours compound 1 was consumed and one major compound was formed and found in the aqueous layer. The aqueous layer was separated and diluted with water and neutralized with $1 \mathrm{~N}$ $\mathrm{HCl}$. The aqueous layer was extracted twice with EtOAc and concentrated to dryness giving a solid which was purified by prep HPLC. An RP-18 Symmetry column $(21 \times 250 \mathrm{~mm})$ was employed and eluted with $25 \%$ aqueous $\mathrm{CH}_{3} \mathrm{CN}$ for 30 minutes followed by $50 \%$ aqueous $\mathrm{CH}_{3} \mathrm{CN}$ for 30 minutes eluting $\mathbf{2}$ at 40 minutes which was lyophilized to give $4 \mathrm{mg}$ of $\mathbf{2}$ as a yellow amorphous powder.

Xanthonol (1)

$[\alpha]_{\mathrm{D}}^{23}+249^{\circ}(c, 1.0, \mathrm{MeOH})$ : soluble in $\mathrm{MeOH}$, DMSO, $\mathrm{CHCl}_{3}$; HRESI-FTMS $(\mathrm{m} / z) 715.2014$ (calcd for $\mathrm{C}_{38} \mathrm{H}_{34} \mathrm{O}_{14}+$ $\mathrm{H}:$ 715.2027), UV(MeOH) $\lambda_{\max } 227$ ( $\varepsilon$ 34,560), 275 $(\varepsilon 7,940)$ and $337(\varepsilon 29,500) \mathrm{nm}$; IR (ZnSe) $v_{\max } 3421$, 2957, 1730, 1604, 1582, 1450, 1362, 1271, 1241, 1173, 1091, 1071, $1027 \mathrm{~cm}^{-1}$; For ${ }^{1} \mathrm{H}$ and ${ }^{13} \mathrm{C}$ NMR data, see Table 1 .

Xanthonolic Acid (2)

HRESI-FTMS $(\mathrm{m} / \mathrm{z}) \quad 597.1617$ (calcd $\mathrm{C}_{30} \mathrm{H}_{28} \mathrm{O}_{13}+\mathrm{H}$ : 597.1608), UV (MeOH) $\lambda_{\max } 230,275,340 \mathrm{~nm} ;{ }^{1} \mathrm{H}$ NMR $\left(\mathrm{CD}_{3} \mathrm{OD}, 400 \mathrm{MHz}\right) \delta 6.53(1 \mathrm{H}, \mathrm{s}), 6.50(1 \mathrm{H}, \mathrm{s}), 4.38(1 \mathrm{H}$, s), $4.33(1 \mathrm{H}, \mathrm{s}), 3.86(1 \mathrm{H}, \mathrm{d}, J=12.8 \mathrm{~Hz}), 3.57(1 \mathrm{H}$, $J=12.8 \mathrm{~Hz}), 2.75(2 \mathrm{H}, \mathrm{m}), 2.36$ (2H, m), 2.15 (2H, m), 2.02 $(2 \mathrm{H}, \mathrm{m}), 2.02(3 \mathrm{H}, \mathrm{s}), 1.99(3 \mathrm{H}, \mathrm{s})$.

\section{Results and Discussion}

\section{Isolation}

Solid state fermentation grown in roller bottles or liquid fermentations grown in shake flasks of the unidentified fungus (MF6460) was extracted with methyl ethyl ketone and the extract was chromatographed on Sephadex LH20 followed by reversed-phase HPLC. The purification was followed by evaluation of each fraction in in vitro assays, using whole organism L. sericata, A. aegypti, and $H$. contortus, and led to the isolation of xanthonol (1, $500 \mathrm{mg} /$ liter) as a pale yellow powder.

\section{Structure Determination}

Xanthonol (1) showed absorption maxima at $\lambda_{\max } 340,275$ and $230 \mathrm{~nm}$ in the UV spectrum indicating that it contained an extended chromophore. HR-FTMS gave a protonated pseudo molecular ion $[\mathrm{M}+\mathrm{H}]$ at $m / z 715.2014$ suggesting a molecular formula of $\mathrm{C}_{38} \mathrm{H}_{34} \mathrm{O}_{14}+\mathrm{H}$ (calculated 715.2027) for 1 . The ${ }^{13} \mathrm{C}$ NMR spectrum (Table 1 ) of $\mathbf{1}$ revealed the 
presence of 38 carbons and supported the molecular formula with 22 degrees of unsaturation. The DEPT spectrum suggested the presence of 3 methyl, 5 methylene and 9 methine carbons which were corroborated by HMQC correlations. The NMR spectra suggested that it was an asymmetrical dimer.

The two methyl groups appeared as singlets at $\delta_{\mathrm{H}} 1.95$ $\left(\delta_{\mathrm{C}} 20.8\right)$ and $\delta_{\mathrm{H}} 1.97\left(\delta_{\mathrm{C}} 20.8\right)$ in the ${ }^{1} \mathrm{H}$ NMR spectrum indicating that they were attached to aromatic carbons $\mathrm{C}-3$ and $\mathrm{C}-3^{\prime}$ which was confirmed by HMBC correlations to three carbons each (Table 1). The third methyl group appeared at $\delta_{\mathrm{H}} 3.73\left(\delta_{\mathrm{C}} 54.3\right)$ and produced an HMBC correlation to the carboxyl carbon $\delta_{\mathrm{C}} 171.3$. The COSY spectrum of xanthonol revealed the presence of two $-\mathrm{CH}_{2}-\mathrm{CH}_{2}-\mathrm{CH}-(\mathrm{O})-$ units and a phenyl ring. Additionally, the ${ }^{1} \mathrm{H}$ NMR spectrum displayed signals for two aromatic proton singlets, one each at $\delta_{\mathrm{H}} 6.36$ and 6.45 , a pair of methine multiplets at $\delta_{\mathrm{H}} 4.26$ and 5.88 assigned to oxygen bearing carbon atoms, two pairs of chelated phenolic groups at $\delta_{\mathrm{H}} 14.01,14.03$ and $\delta_{\mathrm{H}} 11.59,11.48$, and a pair of hydroxy groups at $\delta_{\mathrm{H}} 3.12$ and 3.25 . The ${ }^{13} \mathrm{C}$ NMR spectrum of 1 indicated the presence of two carbonyls $\left(\delta_{\mathrm{C}}\right.$ $\left.166.1, \mathrm{C}-1^{\prime \prime} ; \delta_{\mathrm{C}} 171.3, \mathrm{C}-12^{\prime}\right)$, two enolic carbons $\left(\delta_{\mathrm{C}}\right.$ $\left.180.3, \mathrm{C}-8 ; \delta_{\mathrm{C}} 180.2, \mathrm{C}-8^{\prime}\right)$ and two ketones $\left(\delta_{\mathrm{C}} 188.2\right.$, C$\left.9, \delta_{\mathrm{C}} 188.7, \mathrm{C}-9^{\prime}\right)$. The phenolic group appearing at $\delta_{\mathrm{H}}$ 11.59 gave HMBC correlations to $\delta 160.3$ (C-1), 118.3 (C2) and 105.4 (C-9a) confirming its substitution at C-1 and analogous correlations of $\mathrm{OH}$ appearing at $\delta_{\mathrm{H}} 14.48$ confirmed its connectivity at $\mathrm{C}-1^{\prime}$. HMBC correlations of $\mathrm{H}-5^{\prime}(\delta 5.88)$ to $\mathrm{C}-1^{\prime \prime}(\delta$ 166.1) indicated that the benzoyl group is attached to ${\mathrm{C}-5^{\prime}}^{\prime}(\delta$ 68.9). Similar HMBC correlations of other protons to respective carbons (Table 1) helped assignment of structure $\mathbf{1}$ to xanthonol.

The coupling constants between H-5 and H- 6 of 2.0 and $4.5 \mathrm{~Hz}$ are consistent with an equatorial orientation of $\mathrm{H}-5$, indicating axial orientation of the $\mathrm{C}-5 \mathrm{OH}$. The same is true for $\mathrm{H}-5^{\prime}$ and $\mathrm{C}-5^{\prime} \mathrm{OCH}_{3}$. This is consistent with data reported for structurally similar dimeric xanthones such as dicerandrols [8], neosartorin [9], ascochrome [10] and secalonic acids [11] reported to have antibiotic and cytotoxic activitied.

Xanthonol was hydrolyzed with $\mathrm{LiOH}$ to give xanthonolic acid (2) (Figure 1). The hydrolytic product indicated the absence of the signals of phenyl ring and the methoxy group in the ${ }^{1} \mathrm{H}$ NMR spectrum. In addition, the H-5' $(\delta 5.88)$ was shifted upfield to $\delta 4.38$ indicating the loss of the benzoate group and confirming that the benzoate was located at $\mathrm{C}-5^{\prime}$.

\section{Antiparasitic Activity}

Xanthonol (1) displayed moderate insecticidal and
Table 2 Biological activities of xanthonol (1) and xanthonolic acid (2)

\begin{tabular}{llll}
\hline \multirow{2}{*}{ Compound } & \multicolumn{4}{c}{$\mathrm{LD}_{90}$} \\
\cline { 2 - 4 } & $\begin{array}{c}\text { A. aegypti, } \\
\mu \mathrm{g} / \mathrm{ml}\end{array}$ & $\begin{array}{c}\text { L. sericata, } \\
\mu \mathrm{g} / \mathrm{ml}\end{array}$ & $\begin{array}{c}\text { H. contortus, } \\
\mu \mathrm{g} / \mathrm{ml}\end{array}$ \\
\hline $\mathbf{1}$ & 8 & 33 & 50 \\
$\mathbf{2}$ & $\mathrm{NA} @ 50$ & NA@500 & NA@200 \\
Nodulisporic acid A & 0.5 & 0.3 & NA \\
Paraherquamide & 50 & 50 & 100 \\
Ivermectin & 0.005 & 0.040 & 0.005 \\
\hline
\end{tabular}

NA (not active).

anthelmintic activities against $A$. aegypti, L. sericata, and H. contortus exhibiting $\mathrm{LD}_{90}$ values of 8,33 , and $50 \mu \mathrm{g} / \mathrm{ml}$, respectively (Table 2 ). The hydrolytic product (2) was not active at the highest levels $(50 \sim 500 \mu \mathrm{g} / \mathrm{ml})$ tested. The corresponding biological activities of nodulisporic acid A, paraherquamide, and ivermectin are listed for comparison in Table 2.

\section{Conclusion}

Xanthonol (1), isolated from a non-sporulating fungus, exhibited insecticidal and anthelmintic activities against $L$. sericata, $A$. egypti, and $H$. contortus. This dimeric compound belongs to a growing list of bis-xanthones that exhibit varying biological activities.

Acknowledgments We would like to thank Bruce Michael for providing $H$. contortus bioassay support and Marta Arocho for the initial preparation of the extract for screening.

\section{References}

1. Ondeyka JG, Dombrowski AW, Polishook JP, Felcett T, Shoop WL, Guan Z, Singh SB. Isolation and insecticidal activity of mellamide from Aspergillus melleus. J Ind Microbiol Biotechnol 30: 220-224 (2003)

2. Chabala JC, Mrozik H, Tolman RL, Eskola P, Lus A, Peterson LH, Woods MF, Fisher MH, Campbell WC, Ergerton JR, Ostlind D. Ivermectin, a new broad-spectrum antiparasitic agent. J Med Chem 23: 1134-1136 (1980)

3. Ondeyka JG, Goegelman R, Schaeffer JM, Keleman L, Zitano L. Novel antinematodal and antiparasitic agents from Penicillium charlesii. I Fermentation, isolation and biological activity. J Antibiot 43: 1375-1380 (1990) 
4. Ondeyka JG, Helm GL, Hensens OD, Goetz MA, Zink DL, Tsipouras A, Shoop WL, Slayton L, Dombrowski AW, Polishook JD, Ostlind DA, Tsou NN, Ball RG, Singh SB. Nodulisporic acid A, a novel and potent insecticide from a Nodulisporium sp. Isolation, structure determination, and chemical transformations. J Am Chem Soc 119: 8809-8816 (1997)

5. Ostlind DA, Felcetto T, Misura A, Ondeyka JG, Smith S, Goetz M, Shoop W, Mickle W. Discovery of a novel indole diterpene insecticide using first instars of Lucilia sericata. Med Vet Entomol 11: 407-408 (1997)

6. Henrick CA, Staal CB, Siddall JB. Alkyl 3,7,11-trimethyl2,4-dodecadienoates, a new class of potent insect growth regulations with juvenile hormone activity. J Agric Food Chem. 213: 354-359 (1973)

7. Michael B, Meinke PT, Shoop W. Comparison of ivermectin, doramectin, selamectin and eleven intermediates in a nematode larval development assay. J Parasitol 87: 692-696 (2001)

8. Wagenaar MW, Clardy J. Dicerandrols, new antibiotic and cytotoxic dimers produced by the fungus Phomopsis longicolla isolated from an endangered mint. J Nat Prod 64: 1006-1009 (2001)

9. Proksa B, Uhrin D, Liptaj T, Sturdikova M. Neosartorin, an ergochrome biosynthesized by Neosartorya fischeri. Phytochemistry 48: 1161-1164 (1998)

10. Nielsen RI, Rasmussen FW. (Novo Nordisk A/S). Fungicidally active compounds. U.S. 5,409, 95, April 25 (1995)

11. Franck B, Gottschalk EM, Ohnsorge U, Huper F. Chem Ber 99: 3842-3862 (1966) 